\title{
The Impact of Gadget Use on Psychological Development in Elementary School Children
}

\author{
Rika Widya ${ }^{1}$, Salma Rozana $^{2}$, Munisa $^{3}$, Rita Nofianti $^{4}$ \\ ${ }^{1,2,3,4}$ Lecturer of Faculty Islam and Humanity, Universitas Pembangunan Panca Budi Medan, North Sumatera, \\ Indonesia
}

Corresponding Author: Rika Widya

\begin{abstract}
This paper discussed strategies and solutions that are carried out related to technology equality, namely technology, must be used by all students and potentially supervised by parents, appropriate assessments, preparing enrichment modules, and other things that can enrich literacy. Before learning, some teachers negotiate with students regarding the agreement on using the platform used in learning. Many platforms can be used in online learning, so it can be unclear if they do not focus on a particular platform. In addition to negotiations, it also aims to ensure that all students can access the same technology to support distance learning. Self-regulation is also an effort if it turns out that parental involvement is very weak in the learning process. However, parental involvement in the child's learning process is a must. This study describes how gadgets (positive and negative impacts) impact the mental development of children of developing age in kindergarten and elementary school at the Prof Kadirun Yahya foundation. A qualitative approach research method in this research and be used to examine a condition of a natural object, the researcher as a key instrument, data collection techniques are carried out by triangulation (observation, interviews, documentation), and the results of qualitative research are to understand the meaning, uniqueness, construct phenomena, and find hypotheses. The results of this study are that the use of gadgets has an impact on the psychological development of elementary school children. In this study, five kindergarten children and five elementary school children who used gadgets with a duration of more than 2 hours per day experienced behavioral changes.
\end{abstract}

The impact is positive; children; children are easy to find information about learning and make it easier to communicate with friends. However, the negative impact of gadgets affects psychological development, especially aspects of emotional growth and moral development. In emotional growth, children who use gadgets become irritable, rebellious, imitate behavior in gadgets, and talk to themselves on gadgets. While the effect on moral development impacts discipline, children become lazy to do anything, leave their obligations to worship, and reduce learning time due to playing games and watching YouTube too often.

Keywords: Effect Technologies, Children, Impact Positive and Negative

\section{INTRODUCTION}

With the development and progress of science and technology, on the one hand, we feel happy because we can access information in a relatively short time at a low cost. However, on the other hand, it is very worrying because advances in science and technology like this can hurt the younger generation, especially students (Capovilla et al., 2016). As an example, with the development and advancement of science and technology that is so sophisticated in telecommunications, especially gadgets.

With gadgets that are equipped with complete features, students can access information worldwide in a relatively short time and almost simultaneously and at a relatively low cost so that they can assist students in accessing information related to 
the learning materials provided at the university. School, as a result, student achievement can increase. However, on the other hand, gadgets can also hurt student achievement (Dumond \& Johnson, 2013).

Students or children are "unique" individuals who have potential and experience a process of development. In developing, children need help whose nature and style are not determined by the teacher but by the child himself, in a life together with other individuals (Sitompul et al., 2014).

Development shows a certain process, namely a process that goes forward and cannot be repeated. In human development, some changes are more or less permanent and cannot be repeated. Development is not emphasized in terms of material but terms of functionality. Development also produces new characteristics that progress through the simple stages of an activity to higher stages. Development moves slowly but surely, progressively progressing from the time of conception and ending with death (MARWANTI \& ASTUTI, 2012).

Likewise with childhood. Childhood starts from infancy, namely the age of 2 years, until the child is sexually mature. During the age of 11 years for girls and 12 years for boys, there were significant changes, both physically and psychologically. Childhood is divided into two stages, namely early childhood, and late childhood. Early childhood begins at the age of 2-6 years, while late childhood begins at six years until the child is sexually mature (Nugroho et al., 2018).

When children enter elementary school age, namely the age of 6-12 years, the child's development will be very fast. Not only physical development but also psychological development. They will acquire physical skills while playing and basic skills in reading, writing, arithmetic, and relationships between family and peers (Elizabeth, 2016)v.

Where gadgets are a very popular technology today, children are also always used, so that children are the target of electronic products which have now made children become active consumers of gadget users. An Electronic device that has a special function on each device for example, computers, mobile phones, games, and others.

When children are too busy with the world of their gadgets, they will forget the basic needs of children, namely learning and socializing properly in life. Even children are more engrossed in gadgets than listening to their parents' orders. In addition, there are often people who are angry when ordered by their parents (Nugroho et al., 2018).

Another benefit of gadgets is that they can be connected to the internet. Even their parents are not necessarily able to operate the gadgets they have. (Rachmawati et al., 2017) Gadgets themselves have been in great demand by all groups, especially among students, gadgets have been widely used because they are more practical and fun in the learning process. The gadget has been equipped with very sophisticated features. This can help with learning styles, for example to be able to access a site to find articles or materials being explained. (Marpaung, 2018) Gadgets have many benefits, especially if they are used in the right way and parents should be allowed to introduce gadgets to their children, but it must be remembered that there are positive and negative impacts on these gadgets. But you must be aware that communicating using gadgets also has drawbacks. Gadgets convert sound into electromagnetic waves just like radios (Hawari et al., 2012).

Children like this can be seen every day, especially during the corona covid 19 periods. The use of gadgets without the supervision of parents or teachers can have a bad impact on students because students look at gadgets more often than playing with peers, such as playing soccer or playing games that do physical activity. The researcher once tried to talk to one of the busy students playing games on the gadget, but the answer that came out of the student's 
mouth was very long and seemed reluctant to answer.

When asked by the teacher, the students also did the same thing and did not make eye contact with the interlocutor. So, the impact generated by gadgets and gadgets can damage a child's character that should be good into a bad character (Nugroho et al., 2018).

Although gadgets are not carried out during study hours, this needs special attention from teachers and parents of students. For students who do not bring or have their gadgets will cause jealousy for students. With this regulation limiting the use of gadgets, it is hoped that there will be an increase in the effectiveness, creativity, and independence of the learning process in the education unit, as well as guiding students and parents about the dangers of excessive use of gadgets (Chan \& Shi, 2011).

\section{MATERIALS \& METHODS}

This research method uses a qualitative approach. In principle, qualitative research is a procedure to produce some descriptions of what will be written and what is said by the people who are the target of the research to describe their observable behavior. So that the resulting data is not data in the form of numbers but descriptive words.

Qualitative methods are used to examine an object's natural condition, the researcher is the key instrument, the data collection technique is done by triangulation (observation, interviews, documentation), and the results of qualitative research are to understand the meaning, uniqueness, construct phenomena, and find hypotheses (Sugiyono, 2010). 2007).

The qualitative approach was used because the researcher wanted to find out the impact of using gadgets on the psychological development of children, both negative and positive impacts at student Private School Prof Kadirun Yahya.

\section{ANALYZE AND RESULTS}

They are observing and reviewing the results of observations, in-depth interviews with resource persons, as well as documentation and questionnaires, a general description of the findings and results of research relating to the impact of using gadgets on the psychological development of kindergarten and elementary school-aged children at the Prof Kadirun Yahya Foundation has been presented. Researchers believe that gadgets will have an impact, both positive and negative impacts on children.

Based on the results of observations for three days, it was found that students showed an attitude of responding when spoken to, showing angry expressions, comfortable in class, able to complete assignments at school, able to control emotions, carry out picket according to schedule, comfort friends who are sad, donate some pocket money, carry out worship, respect others, and be able to obey the rules at school.

The medium category is $42 \%$ with the duration of using gadgets for less than 1 hour or 40-60 minutes a day, while the other $32 \%$ are in the low category with gadget usage 5-30 minutes a day and very rarely using gadgets at home or only in their spare time. . So, the researchers got ten children who use gadgets more than 2 hours a day.

Children use gadgets to open the Internet, YouTube, and games. Children's addiction levels vary, such as the hands cannot stay still when not holding the gadget, cry when the gadget is taken, and often imitate the movements in games often played. Children are kind to others. Children are always careful when talking and behaving. The child does the job well. Children can communicate well with the people around them.

Children can help friends who are experiencing disaster or difficulty and provide motivation or encouragement. Children can carry out religious teachings, such as praying five times a day, praying, and fasting during the month of Ramadan. 
Children can be polite to older people, apologize when they make mistakes, and tell the truth.

The results of filling out a questionnaire on the child's parents found that the parents agreed if the child used the gadget for less than 1 hour a day or during free time. Since getting to know gadgets, children often rebel or argue, preferring to play with gadgets at home than playing outside with friends. The child often shows an annoyed or angry expression. Children can adapt to new environments, are responsible for their duties, help parents work at home. Be polite to elders, and obey the rules at school and home.

Moreover, children's interviews state that children use gadgets more to play online games and watch YouTube, occasionally open the internet to help learn and communicate via WhatsApp. Children say that gadgets do not affect their behavior and achievement in school; children have not been able to control emotions and feel panic. However, children can adapt well to new environments. Able to tolerate religions, respect people's opinions, speak politely to older people.

The results of interviews with children's parents said that children use gadgets to play online games and watch YouTube, and occasionally use WhatsApp to communicate with friends and open the internet to learn.

The results of interviews with teachers and principals said that schools never allow children to bring gadgets to school. The teacher also suggests that their use is limited to only 1 hour and on holidays when children are at home. For normal days it is allowed for learning facilities, but must be accompanied by parents.

The teacher suggests that children use applications that are useful for learning tools. If the gadget is used properly, it can help with learning, but when the gadget is only used to play games, it will have a bad impact on children; for example, children become lazy, careless, children become ignorant and affect children's vision so that it will interfere with children's learning at school.

Children in class V cannot control their emotions yet; there must be guidance from the teacher. Likewise, in decisionmaking and problem-solving, children must always be given direction and guidance from the teacher; if the child is not directed, the child will fight with his friends. Children have good social behavior, such as helping friends who are in trouble, comforting friends who are sad, visiting sick friends, and voluntarily donating some of their pocket money to be donated. Some children will argue if they are told or given advice; some like to interrupt the teacher's conversation, but the teacher will immediately take firm action so that the child does not repeat the bad behavior.

Children can carry out religious teachings well, such as praying and praying before starting lessons. Children communicate politely when with the teacher but often talk casually when with their friends, causing fights. Children also need assistance in increasing self-confidence.

\section{CONCLUSION}

Based on the results of research and discussion in Chapter IV, it can be concluded that gadgets have an impact on the psychological development of elementary school children. In this study, ten children in class $\mathrm{V}$ (five) who used gadgets with a duration of more than 2 hours per day experienced behavioral changes.

The impact is positive; children are easy to find information about learning and make it easier to communicate with friends. However, the negative impact of gadgets affects the psychological development of children, especially aspects of emotional growth and moral development. In emotional growth, children who use gadgets become irritable, rebellious, imitate behavior in gadgets, and talk to themselves on gadgets. While the effect on moral development impacts discipline, children become lazy to do anything, leave their 
obligations to worship, and reduce learning time due to playing games and watching YouTube too often.

After analyzing the impact of using gadgets on the psychological development of elementary school children, there are several suggestions that the authors convey, including the following:

1) For children, it is expected to be able to reduce the frequency of using gadgets so that they can improve children's ability to control themselves not to play gadgets excessively.

2) For teachers, it is expected that they can use gadgets as learning media in the classroom.

3) Parents and teachers are expected to help supervise, assist, and limit the use of gadgets and deviant behavior of children so that children can control their behavior and speech.

4) For further researchers interested in conducting the same research as the researcher, they should pay attention to other aspects of the psychological development of elementary school children.

\section{Acknowledgement: None}

\section{Conflict of Interest: None}

\section{Source of Funding: None}

\section{REFERENCES}

1. Capovilla, D., Hubwieser, P., \& Shah, P. (2016). DiCS-Index: Predicting student performance in computer science by analyzing learning behaviors. Proceedings 2016 International Conference on Learning and Teaching in Computing and Engineering, LaTiCE 2016, 136-140. https://doi.org/10.1109/LaTiCE.2016.12
2. Chan, T.-F., \& Shi, K. (2011). Applied Intelligent Control of Induction Motor Drives. In Applied Intelligent Control of Induction Motor Drives. https://doi.org/10.1002/9780470825587

3. Dumond, E. J., \& Johnson, T. W. (2013). Managing university business educational quality: ISO or AACSB? Quality Assurance in Education, 21(2), 127-144. https://doi.org/10.1108/0968488131131067 4

4. Elizabeth, R. (2016). Pemberdayaan Wanita Mendukung Strategi Gender Mainstreaming dalam Kebijakan Pembangunan Pertanian di Perdesaan. Forum Penelitian Agro Ekonomi, 25(2), 126. https://doi.org/10.21082/fae.v25n2.2007.12 6-135

5. Hawari, K., Ghazali, B., Ma, J., Xiao, R., \& Aryza, S. (2012). An Innovative Face Detection Based on $\mathrm{YCgCr}$ Color Space. Physics Procedia, 25, 2116-2124. https://doi.org/10.1016/j.phpro.2012.03.358

6. MARWANTI, S., \& ASTUTI, I. (2012). Model Pemberdayaan Perempuan Miskin Melalui Pengembangan Kewirausahaan Keluarga Menuju Ekonomi Kreatif Di Kabupaten Karanganyar. SEPA: Vol. 9 No.1, 9(1), 134-144.

7. Nugroho, A. D., Waluyati, L. R., \& Jamhari, J. (2018). Upaya Memikat Generasi Muda Bekerja Pada Sektor Pertanian di Daerah Istimewa Yogyakarta. JPPUMA: Jurnal Ilmu Pemerintahan Dan Sosial Politik Universitas Medan Area, 6(1), 76. https://doi.org/10.31289/jppuma.v6i1.1252

8. Sitompul, R., Of, U., Sumatera, I., North, M., \& Indonesia, S. (2014). Implementation Analysis Against Children In Marriage. 2.

How to cite this article: Widya R, Rozana S, Munisa et.al. The impact of gadget use on psychological development in elementary school children. International Journal of Research and Review. 2021; 8(8): 314-318. DOI: https://doi.org/10.52403/ijrr.20210843 